\title{
GEOGRAPHICAL PATTERNS \\ OF POPULATION AGING IN RUSSIA
}

\section{ARTUR Petrosian, EgOR SHEVChuK, PAVEL KiRILlov, Nikita MOZgUnOV}

\begin{abstract}
The paper investigates the geographical features of demographic ageing using the age of retirement as the main definition for the old age boundary. The study is based on demographic statistics of Rosstat and the UN Population Division. The possible interdependence between population ageing and the implementation of social policies in the field of pension regulation is studied. The hypothesis about the relationship between low levels and a high pace of population ageing for countries of the world and regions of the Russian Federation was tested.
\end{abstract}

A cartographic and statistical analysis of spatial data at the level of regions and municipalities made it possible to identify and describe the main geographical factors of population ageing differentiation. The 'ethnic' subjects of the Russian Federation, as well as the Northern regions of new development (autonomous okrugs), where a minimum proportion of the elderly of retirement age is observed, are growing older the most rapidly. At the same time, the echo of social crises that took place during the 20th century still plays a significant part in the pace of ageing. However, over the course of this century its influence will increasingly weaken.

\begin{abstract}
At the local level, ethnic and rural-urban differentiation is becoming a less significant factor of population ageing in comparison with migration: the working-age population continues to concentrate in the largest urbanised areas. The main territories of the "young" population concentration are the administrative centres of Russia's regions and areas with a high proportion of non-Russian ethnic groups with a high total fertility rate (TFR), as well as some other 'azonic' municipalities.
\end{abstract}

Key words: population ageing, retirement age, spatial differentiation, pension reform, demographic burden rate.

Population ageing is one of the most important challenges for national economies in the current century. One way or another, all regions of the world during the 21 st century will face the problem of an increasing proportion of representatives of older age cohorts (Scherbakova 2014: 26-51; Lutz, Sanderson, Scherbov 2008). Regional differences in the age structure of the population most often owe their existence to the fact that different territories are simultaneously at different stages of the demographic transition.

\section{DEMOGRAPHIC AGEING AND RAISING THE RETIREMENT AGE}

The focus of the study is the population of retirement age - people who in the modern world, of course, are not always "elderly" or old. However, given the ambiguity of the term "old age" itself, it seems more logical to use a legal definition as a threshold for the retirement age, a concept which plays a significant role in balancing the pension system and the labour market (Maleva 2010) and at the same time can reflect the processes of population ageing.

\footnotetext{
Artur Petrosian (artur29031@mail.ru), Lomonosov Moscow State University, Russia.

EgOR SHEvCHUK (egor.shevchuk@mail.ru), LOMONOSOv MOSCOW STATE UNIVERSITY, RuSSIA.

Pavel Kirillov (linard@mail.ru), Lomonosov Moscow State University, Russia.

Nikita Mozgunov (mozgunoff@list.ru), Lomonosov Moscow State University, Russia.

THE ORIGINAL ARTICLE IN RUSSIAN WAS PUBLISHED IN DEMOGRAPHIC REVIEW 2019. 6(2): 55-83.

DOI: 10.17323/DEMREVIEW.v6I2.9872
} 
Table 1. The degree and pace of the old age dependency ratio in countries where the age of retirement has been increased

\begin{tabular}{|c|c|c|c|}
\hline $\begin{array}{l}\text { Year of start } \\
\text { of pension } \\
\text { reform }\end{array}$ & Country & $\begin{array}{l}\text { Old age dependency ratio (persons } \\
\text { over } 65 \text { years of age per persons of } \\
\text { working age ( } 15-64 \text { years) }\end{array}$ & $\begin{array}{c}\text { Average annual growth rate of the } \\
\text { old age dependency ratio for the } 6 \\
\text { years preceding the start of } \\
\text { reforms, } \%\end{array}$ \\
\hline 2000 & Japan & 249 & 3.22 \\
\hline 1993 & Latvia & 198 & 2.09 \\
\hline 1993 & Estonia & 196 & 2.07 \\
\hline 2019 & Russia & 208 & 2.01 \\
\hline 1993 & Lithuania & 178 & 1.93 \\
\hline 2018 & Estonia & 303 & 1.91 \\
\hline 1995 & Italy & 242 & 1.89 \\
\hline 2014 & Latvia & 289 & 1.46 \\
\hline 2018 & Belarus & 216 & 1.46 \\
\hline 2012 & Lithuania & 264 & 1.19 \\
\hline 2000 & Germany & 243 & 1.17 \\
\hline 2008 & Italy & 305 & 1.12 \\
\hline 2012 & Germany & 316 & 1.02 \\
\hline 2016 & Kazakhstan & 104 & 0.79 \\
\hline 2010 & UK & 252 & 0.59 \\
\hline 2011 & Ukraine & 224 & -0.46 \\
\hline
\end{tabular}

Source: (World Bank 2017).

The decision to increase the age threshold for retirement does not always depend on the current level and rate of population ageing (table 1). Such public policy measures are extremely unpopular and therefore often belated, since they rely on sufficient political will and broad support for the government's course.

Most likely, the decision to raise the retirement age is more related to the economic situation than to the demographic context, as noted by researchers on the socio-economic effects of ageing populations (Reher 2011). Thus, reforms that involve raising the retirement age take place in different demographic circumstances.

In many European countries, population ageing continues, but at a slower pace. A second wave of raising the retirement age is taking place in a more stable demographic situation: in 20102020 there has been a tendency towards stabilization of the growth rate of the proportion of people over 65 at the level of 1.5\% per year (Disney, Johnson 2001; Dorn, Sousa-Poza 2010). In Russia today there is an increase in the rate of population ageing which the countries of Western, Central and Southern Europe (Spain, Portugal, Greece and Italy) experienced in the 1970s and 1980s, and the Baltic States (like the rest of Eastern Europe) - in the 1980s and 1990s. The rate of ageing of the Russian population is even higher if we consider the "old" population in the retirement age range that was in effect until recently. Thus, the decision to raise the retirement age occurred 1015 years later than the optimal time (the beginning of the 2000 s, when the workforce was still growing).

The retirement age was raised in 13 of the 15 post-Soviet countries. However, ageing trends in the former republics of the Soviet Union vary. So, in Central Asia, largely due to both the high fertility after the crisis of the 1990s and the outflow of the Russian-speaking population, characterised by an "older" age structure, the problem of demographic ageing as a factor in destabilization of the solidary pension system will become relevant only in the 2040-50s. Under 
the current demographic situation, the reform in these countries was more tied to attempts by the authorities of these countries to reduce the budget deficit arising due to economic factors, at the same time partially protecting itself from an increase in pension expenses in the future.

Ukraine, by contrast, is an example of an increased retirement age that coincided with a short-term decrease in the demographic burden rate for people over 65 . The reason for this was the effect of the demographic echo - older age cohorts in the 2000s were replenished with people born in 1932-1945 (famine and political terror, World War II). The difference from the Russian Federation is in the longer duration of this period due to the greater role of social disasters of the 1930s in the Ukrainian SSR, as well as a more pronounced peak in fertility in rural Ukraine in the 1980s (it was these cohorts that entered working age throughout the 2000s). Nevertheless, the country 8 years ago had a higher level of demographic burden than is observed today in Russia, which also indicates the "belated" nature of raising the retirement age.

\section{THE PLACE OF RUSSIA IN AN AGEING WORLD}

When considering the demographic burden rate of the elderly (over 65 years), the Russian Federation is in 49th place out of more than 200 world states and dependent territories. Similar values of the indicator are observed in developing countries that completed the demographic transition quite early: countries of Latin America and the Caribbean, where a population of European descent predominates (Argentina, Cuba), as well as relatively young countries in Europe, where Catholic Christianity is traditionally strong (Ireland, Slovakia).

However, Russia and Belarus, which have similar indicators both in terms of the level and the rate of its change, are characterised by lower growth rates of the demographic burden among older people over 65 (2\% versus 3-4\%). A similar fact can be explained by the significant lag of the post-Soviet countries in solving the problems of the second epidemiological transition (Vishnevsky 2015: 12-13). Prevention measures that are actively used in the above-mentioned European and Latin American countries can increase life expectancy and improve its quality.

In the countries of Latin America, values of the level of demographic old age are similar to those in Russia. The higher rates of population ageing in this region are mainly explained by the fact that they simultaneously cause a sharp decrease in the number of representatives of younger age cohorts (birth rates are higher than in Russia and are rapidly declining) and an increase in the age of survival at older ages (Vishnevsky 2005).

The concept of a demographic transition, the last phase of which is characterised by population ageing, suggests higher rates of ageing in the countries of the world that have only recently entered it (low ageing), and vice versa, lower ones in areas where population ageing has begun earlier. To assess any possible connection, the indicator of the old age dependency ratio (the most common threshold of the retirement age) was used. To calculate the "speed" of ageing, the average annual rates for the five-year period preceding the year for which the ageing level was calculated were chosen. In our opinion, the use of this indicator allows one to get rid of possible volatility in the calculation for shorter periods, and also corresponds to the "current" speed of the process at the time of the study. 


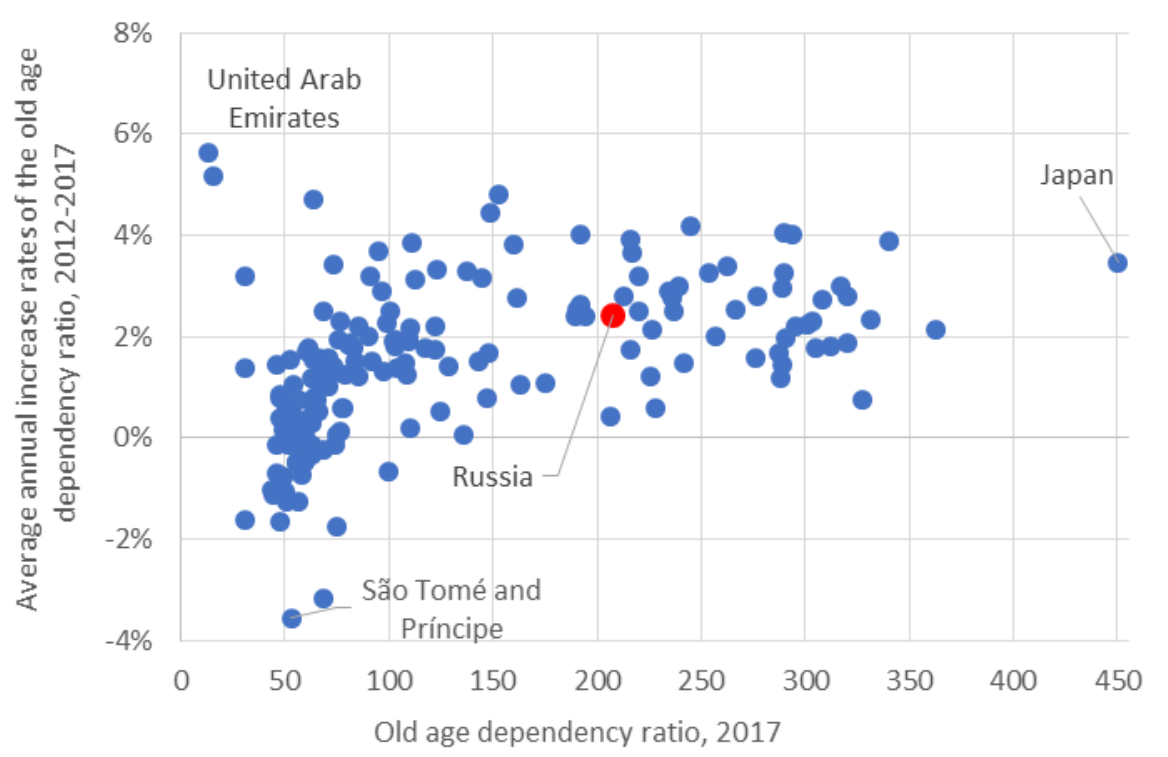

Figure 1. The achieved level and rate of old age dependency ratio in the countries of the world (UN member states with the exception of "dwarf" countries), \%

Source: (UN World ... 2017).

No significant linear relationship at the country level was found (Figure 1). Nevertheless, the following difference can be traced: countries that are completing the demographic transition (high burden for the elderly) are characterised by approximately the same rate of increase in the indicator $(2 \ldots 4 \%)$, while in countries with a low burden the rates vary significantly $(-4 \ldots 6 \%)$.

Europe and Japan, as well as the USA, Canada and Australia, belong to the first group: the demographic transition in these areas took place in a similar way (a sharp increase in the population, then a transition to contracted reproduction and, as a consequence, the ageing of the population). Countries with a low burden have different trajectories: the least developed of them (for example, the Central African Republic, Chad, and Haiti) experienced a sharp decrease in mortality, but steadily high fertility rates do not allow us to speak of a change in the age structure of the population towards ageing. Moreover, in countries with the world's highest fertility indicators and a decrease in infant mortality, a decrease in the demographic burden of the elderly is observed. On the contrary, more developed countries that have a significantly deformed age structure due to migration (for example, the Arab states - Qatar, United Arab Emirates) are characterised by an average annual rate of $4-6 \%$. 


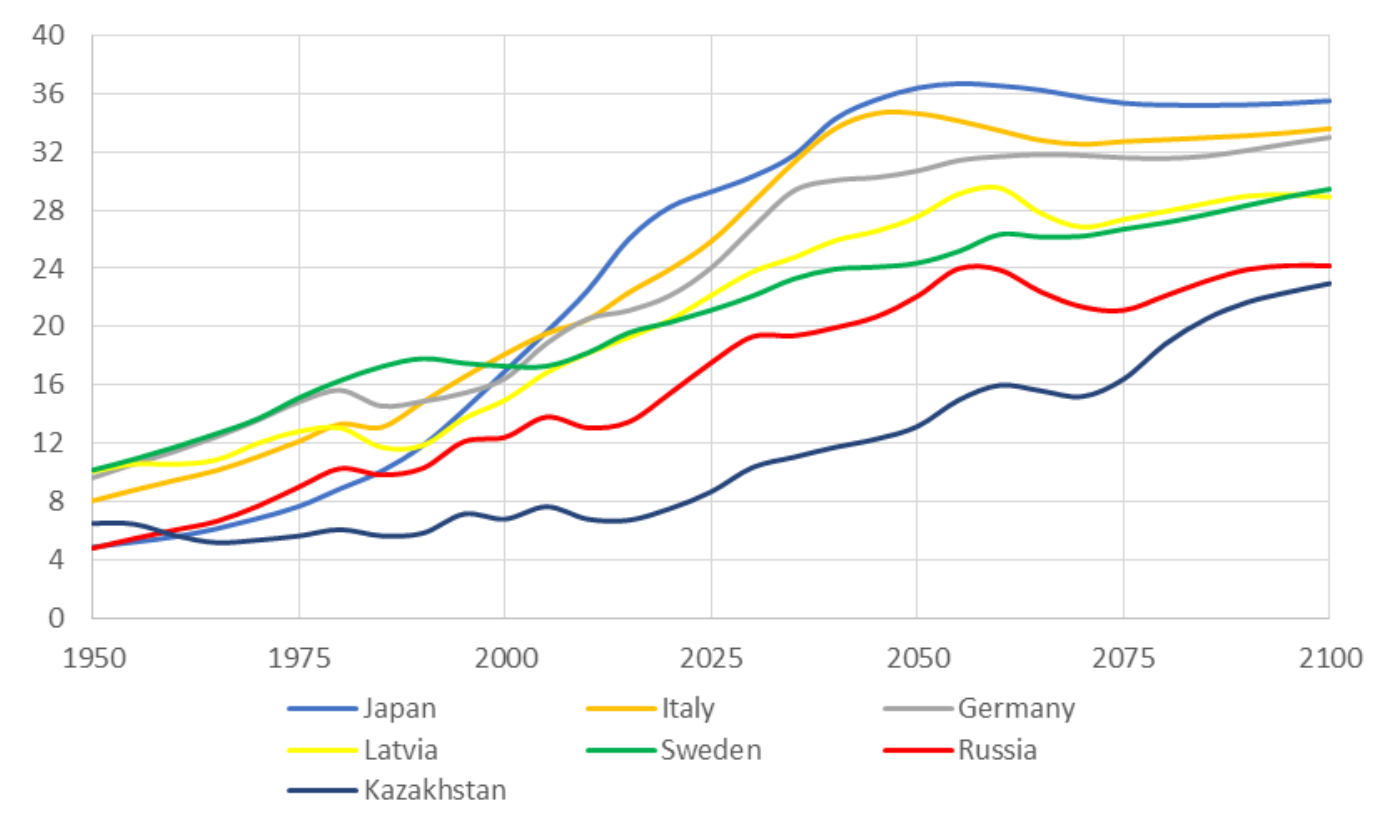

Figure 2. Proportion of population over 65 in some countries of the world in 1950-2100, \%

Source: (UN World ... 2017).

Note: Values for 2020-2100 are given according to the average version of the UN forecast.

When considering the long-term dynamics of the proportion of the elderly $(65+)$ in the Russian Federation against the background of some countries of Eurasia (Figure 2), there appears such a feature of the age-gender structure as sharp changes in the number of neighboring generations (consequences of the Second World War in the countries of the former USSR). Russia, Kazakhstan and, to a lesser extent, Latvia are characterised by a short-term slowdown in growth and even a decrease in the proportion of elderly people every 25 years (in the 2000s, older age cohorts were replenished by the extremely small generation born during World War II).

Also worthy of attention is the time lag of the degree of demographic ageing between Russia and developed countries. Its duration has an unstable tendency to decrease from 35-40 years in the 1980s to 25-30 years now and in the near future. In the future, the "lag" of the Russian Federation in terms of demographic ageing will also be associated with a gap in life expectancy with more developed countries. 


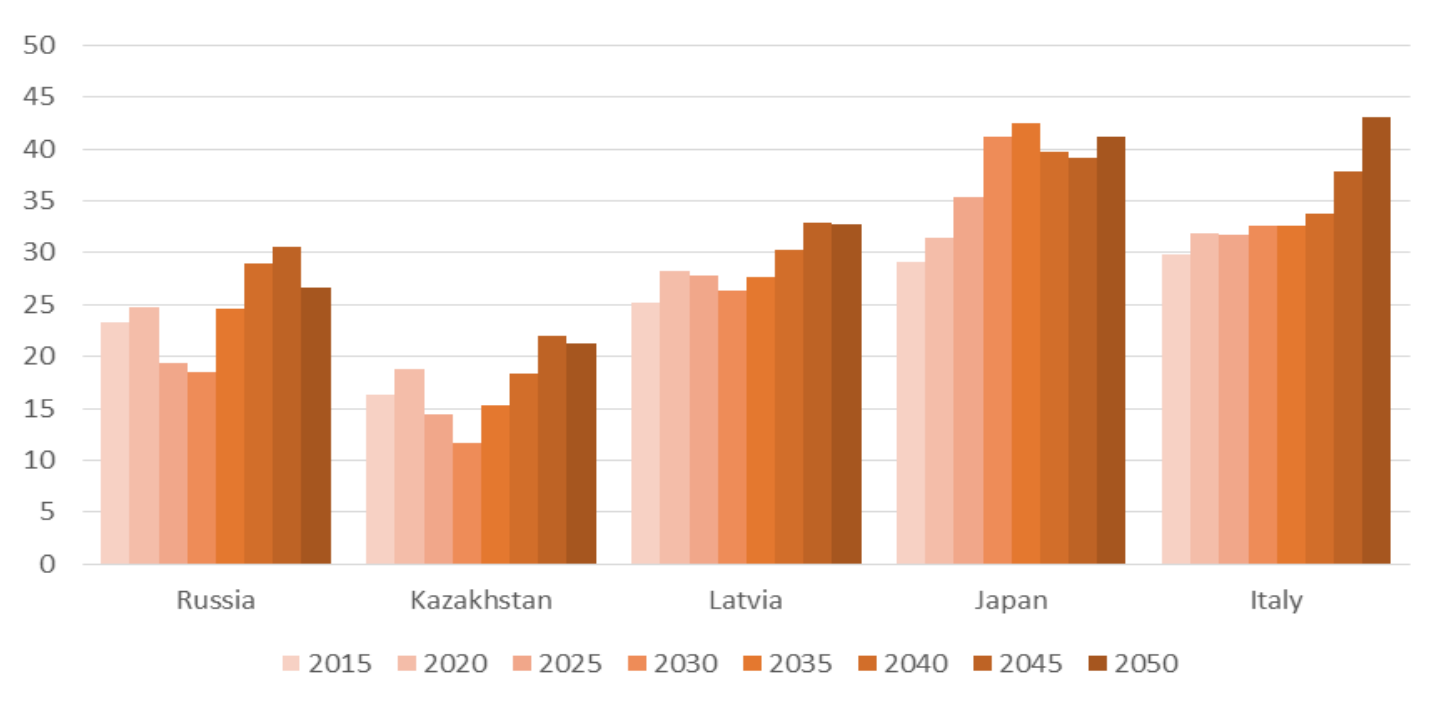

Figure 3. The depth of ageing index in Russia and some foreign countries, (the share of the population aged $80+$ in the population $65+$ ), 2015-2050, \%

Source: (UN World ... 2017).

Note: Values for 2020-2100 are given according to the average version of the UN forecast.

Unlike developed countries, Russia has a low “depth of ageing” (Figure 3), which means the proportion of the oldest (over 80 years old) among the elderly (over 65 years old). An increase in life expectancy generally leads to an increase in the depth of ageing. However, in the case of Russia, the dynamics may be complicated by the characteristics of the age-sex structure of the population. When the large cohorts of the 1950-60s enter the non-working age, there may be, compared with the narrowed generation born during WWII, a short-term decrease in the indicator.

For post-Soviet countries, the growth trend is interrupted in 2025-2030 and again becomes noticeable after 2045. Nevertheless, in the second half of the 21 st century the influence of the demographic echo of war on the heterogeneity of the age structure will decrease (the difference between the number of neighboring large and small age cohorts decreases with each new generation).

Russia is currently experiencing a new round of growth in the proportion of elderly people, which is largely determined by the continued entry into retirement age of a sufficiently large cohort of those born in the early 1960s and the simultaneous replenishment of the working-age population by the small generation of the 1990s. Other features of demographic ageing in Russia are its insignificant "depth" (low age of survival for people over 60) and distinct interregional imbalances (various trajectories of the demographic transition in the constituent entities of the Russian Federation).

\section{REGIONAL DIFFERENTIATION OF THE PROPORTION OF RETIREMENT-AGE PERSONS IN THE REGIONS OF RUSSIA}

The regions of the Russian Federation, despite their equal legal status, cannot be considered territorial units of the same taxon. They are a heterogeneous group that includes region-cities 
(Moscow with a population of 12.5 million people and St. Petersburg with 5.5 million), regions of Central Russia with approximately the same number and structure of the population, and "ethnic" republics and autonomous districts which in terms of population and economic potential are sometimes comparable only with individual municipal areas of larger entities. Such a situation creates conditions for inter-regional differentiation associated with factors such as the level of urbanization and the ethnic structure of the population, which can significantly differ from the Russian average within the "special" regions (ethnic republics, the Arctic zone, federal cities).

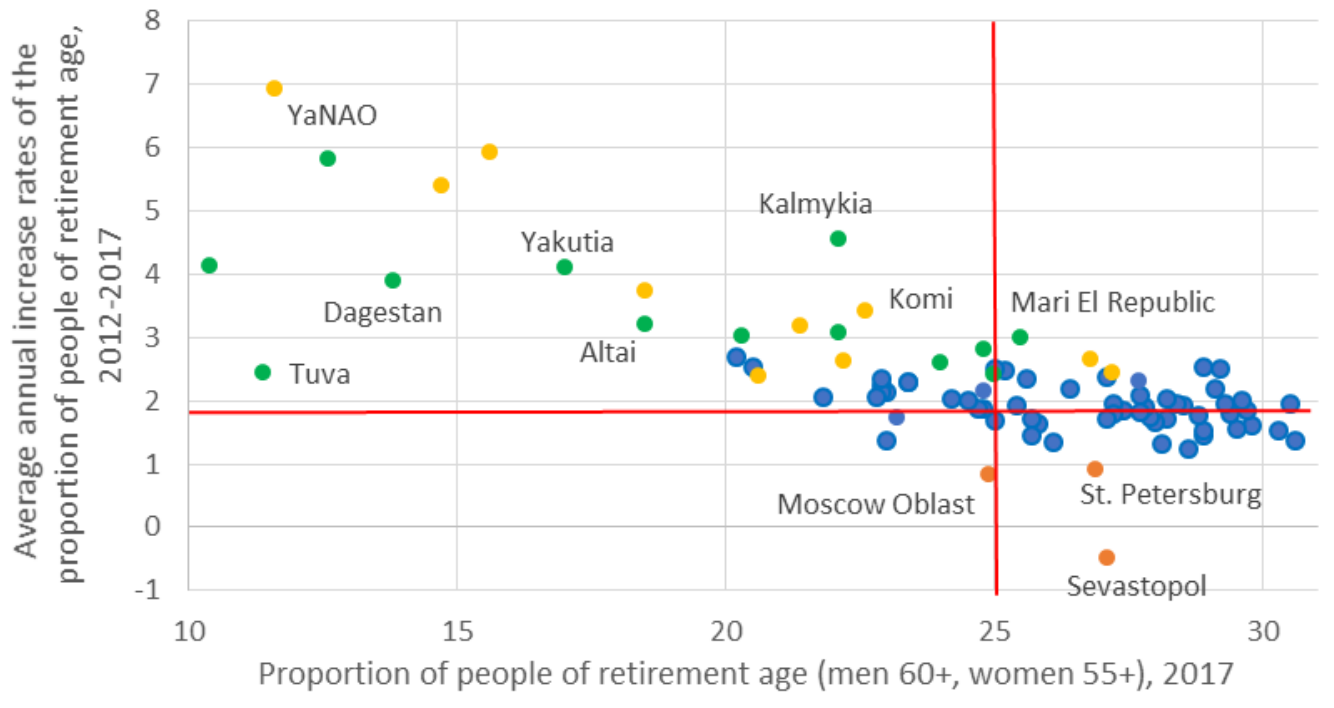

\section{Figure 4. The achieved level and rate of population ageing (men $60+$, women $55+$ ) in the regions of the Russian Federation, \%}

Source: (Rosstat 2018b).

Note: The colors highlight the regions belonging to specific groups in which indicators deviate from the national average (red lines): green - ethnic republics (with high proportion of non-Russian ethnicities), yellow - regions of the Far North, red - leaders in migration growth.

The highest rates of ageing are observed in regions characterised by a low proportion of people of retirement age (Figure 4): the republics of the eastern zone of the North Caucasus with a high share of the rural population, as well as in the Siberian and Far Eastern republics (Yakutia, Altai). At the same time, the Republic of Tuva, where the factor of extremely low life expectancy is added to high fertility, is experiencing a much more modest increase.

The northern regions of new development are also rapidly ageing: younger oil producers (Nenets, Khanty-Mansi and Yamalo-Nenets autonomous okrugs) and older regions of the Russian North and Far East (Arkhangelsk Oblast, Komi Republic, Chukotka Autonomous Okrug, Magadan Oblast).

The most slowly ageing regions are characterised by a relatively high level of retirement age. In addition to low fertility, these regions owe their low growth rates also to an influx of working-age people: the Moscow Region, St. Petersburg and Sevastopol are examples of federal centers of attraction for migrants. 
If we consider those regions of the Russian Federation characterised by a 23-30\% level of people older than the retirement age and an average annual growth rate of $2 \%$, then a relationship between the indicators is practically not observed. A similar fact may indicate a significant effect in the "old" regions of not only minor differences in fertility, but also of the migration situation. Thus, in most regions of the Russian Federation, where about 2/3 of the country's population lives, demographic ageing occurs relatively evenly, while maintaining small differences within this group.

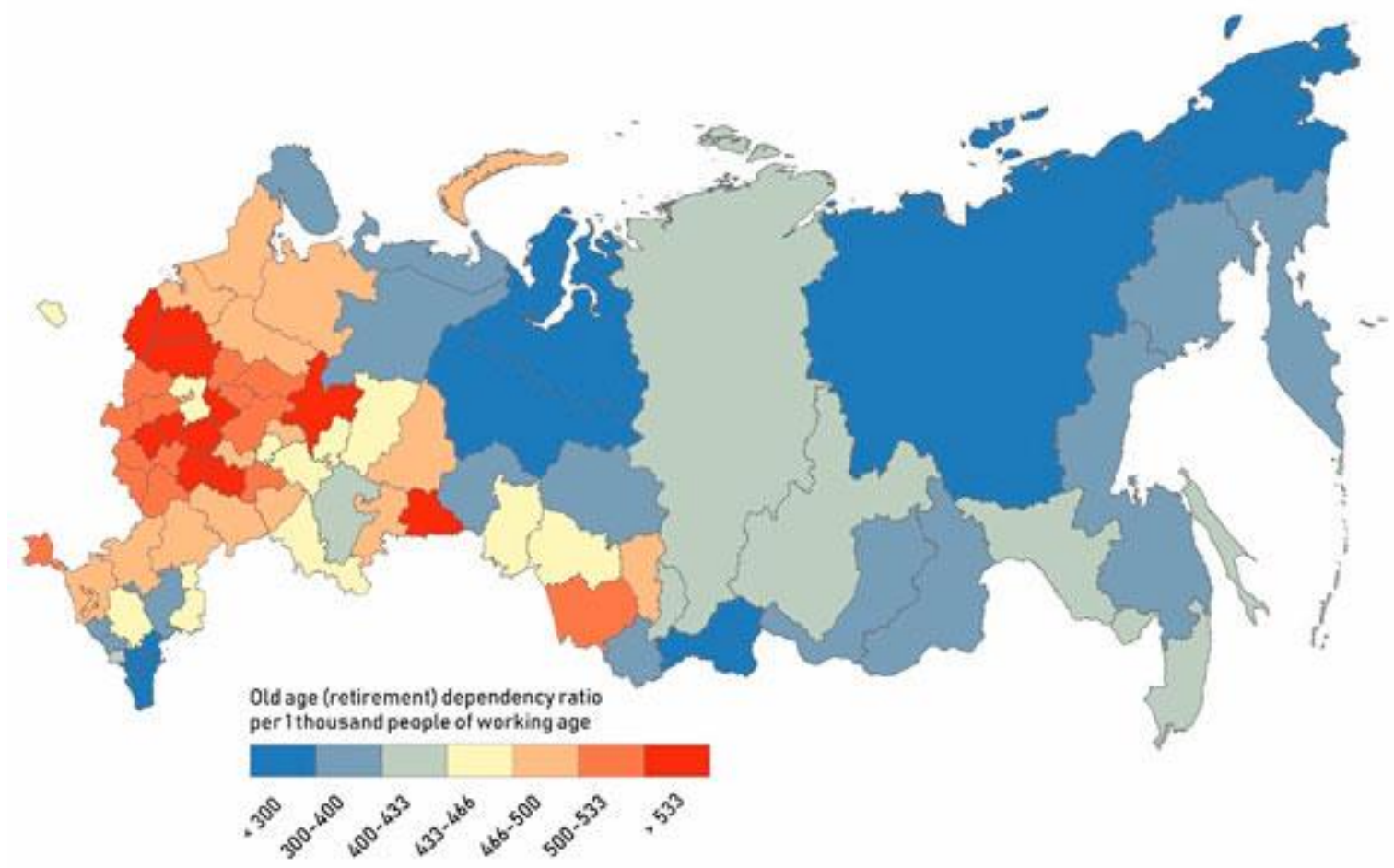

Figure 5. Old age (retirement) dependency ratio in the regions of Russia (men 60+ and women 55+), per 1 thousand people aged 15-54 (59) years, 2017

Source: Compiled by the authors based on (Rosstat 2018b).

In contrast to the share indicator, the pension burden rate makes it possible to identify regions where a high proportion of people of retirement age is associated with a low size of the working-age population. Such examples are the constituent entities of the Russian Federation that have become migration donors for neighboring agglomerations (Figure 5): the regions of the Central Federal District, the Volga Federal District and the North-Western Federal District for Moscow and St. Petersburg, the Kurgan Region for Yekaterinburg and to a lesser extent Chelyabinsk. On the contrary, such regions as Moscow, St. Petersburg, the Leningrad, Moscow, Kaliningrad and Voronezh oblasts, despite a high proportion of pensioners, are characterised by a lower burden (due to the influx of people of working age from other regions). 

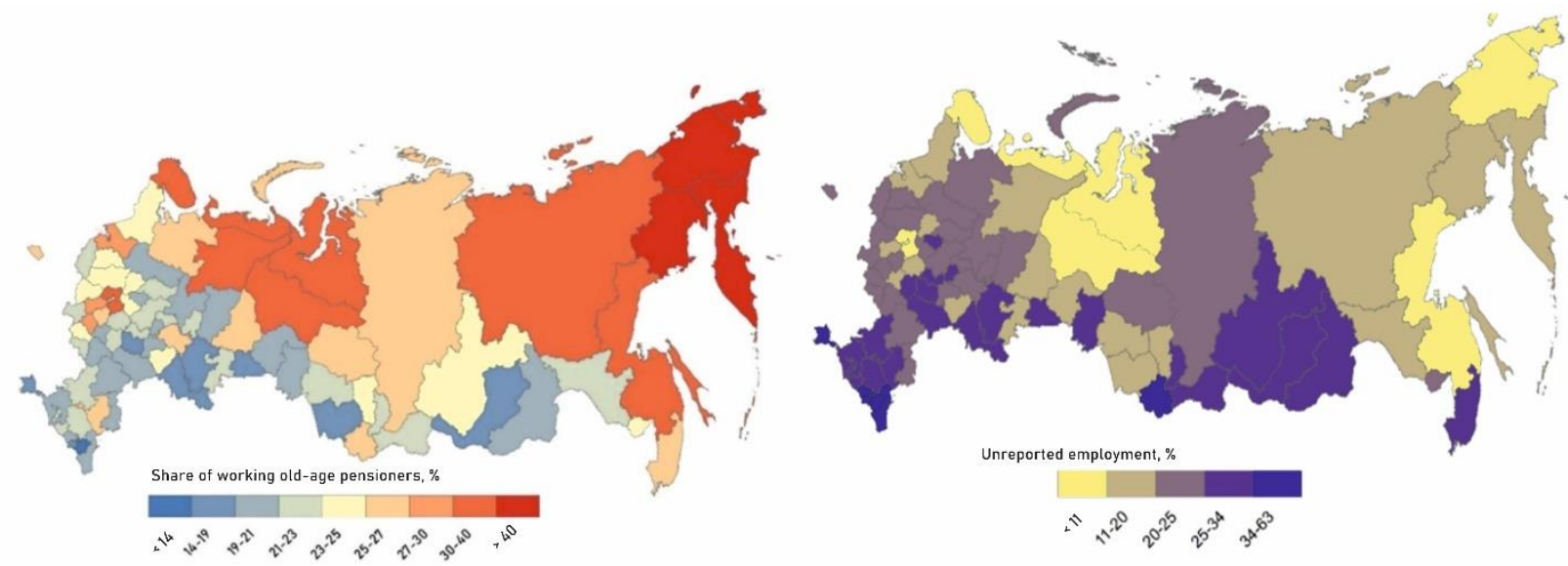

Figure 6. The proportion of working old-age pensioners in the regions of Russia and unreported employment (the proportion of people employed in the unreported sector between the age of 15-72 years), 2017, \%

Source: Compiled by the authors based on (Pension Fund ... 2018; Rosstat 2017b).

The transformation of local labour markets in an ageing population is not universal: there is no correlation between the proportion of persons of retirement age in the population of the region and the proportion of working pensioners. The main differentiation at the regional level is expressed in a north-south dichotomy (Figure 6). In areas of the Far North and their equivalents, which include most of the regions of the North of the European territory of Russia, Siberia and the Far East, the proportion of working pensioners is significantly higher (Sonina, Kolosnitsyna 2015). This is due to the earlier retirement threshold available to those with sufficient working experience in such territories. The level of participation in the labour force among younger cohorts of the population (50-55 years old) significantly exceeds that of "ordinary" pensioners (55-60 years old). However, the main reason is the significant statistical undercounting of working pensioners, especially in regions with a high share of workers in the informal sector.

There is also a high proportion of working pensioners in the largest urban agglomerations (Moscow, St. Petersburg, Moscow and Leningrad oblasts) and developed regions with a diversified economy (Sverdlovsk oblast, Tatarstan), where, due to a higher quality of life and higher life expectancy, a model of active working age has partially formed (Belyaeva 2006: 5556). At the same time, in Moscow itself, the proportion of pensioners who continue to work is slightly lower, which may be due to a fairly high level of pensions with significant regional allowances.

The smallest share of working pensioners is observed in the southern, more rural regions. There are several possible factors behind the low level of participation in the labour force for persons receiving an old-age pension. Firstly, many representatives of the older generation in regions with favorable agro-climatic conditions have a plot of land where they can grow products both for sale and for their own basic needs. Secondly, in some less urbanized "titular" regions, relations between the older generation and their children and grandchildren, who often form a single household with them, are much more significant. Material support from children is an integral part of a traditional family, widespread, for example, in the regions of the North Caucasus (Mironova 2014). 


\section{PROSPECTS FOR THE DYNAMICS OF POPULATION AGEING IN THE REgIONS OF RUSSIA TILL 2035}

Based on the official demographic projection of Rosstat (middle scenario), the proportion of the population older than retirement age was calculated (Rosstat 2017b). As its boundaries, pre-reform values were used: 55 and 60 years for women and men, respectively. The dynamics of the indicator were analysed according to growth rates in three five-year periods: 2020-2025, 2025-2030 and 2030-2035.

First, let's study the dynamics of the largest territorial units. Most convenient for such an analysis is not the common statistical grouping by federal districts, but the more current and detailed grid of macro-regions used in the Strategy for Spatial Development of Russia until 2025 ${ }^{1}$.

In all macroregions (Figure 7), with the exception of the North Caucasus, the increase in the specific indicator is higher than the increase in the absolute number of people over 55 (60) years of age: the ageing of the population will occur not only due to an increase in the number of pensioners, but will also be accompanied by a decrease in the number of children and persons of working age. An additional factor in some macroregions (South Siberian, Far Eastern, AngaraYenisei, Northern) is not only and not so much a decrease in fertility as a migration loss of a younger and more mobile population. The highest increase in the number of people of retirement age is expected to be observed in the North Caucasus, the Center and the Northwest (only due to Moscow, St. Petersburg and, to a much lesser extent, Kaliningrad).

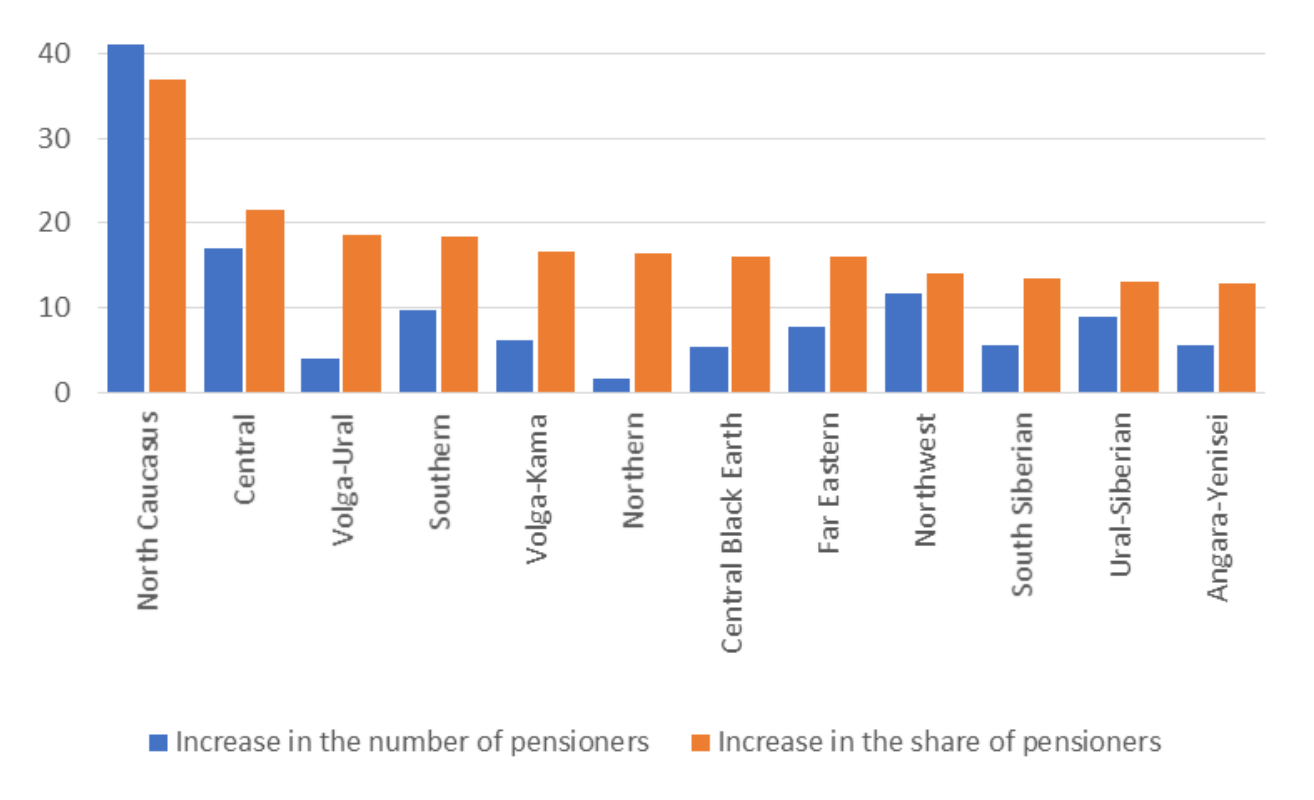

\section{Figure 7. Dynamics of indicators of demographic ageing in the macro-regions of Russia} (men 60+ and women 55+), 2017-2035, \%

Source: (Rosstat 2017a).

An example of a significant ageing of the population without a corresponding increase in the number of pensioners is the Northern and Volga-Ural macro-regions. A similar trend is

\footnotetext{
${ }^{1}$ Approved by Order of the Government of the Russian Federation February 13, 2019 No. 207-r.
} 
determined not only by a decrease in migration, but also by a significant decrease in the relatively high fertility in the rural areas of these territories.

In 19 constituent entities of the Russian Federation, an increase in the share of pensioners and the pension burden will be accompanied by a decrease in their number. First of all, these are the demographically oldest regions of the European part of Russia: Vladimir, Ivanovo, Oryol, Tambov, Tver, Tula, Arkhangelsk, Murmansk, Novgorod and Pskov oblasts. This group of regions also includes regions of the Volga region (Kirov, Nizhny Novgorod, Penza and Ulyanovsk oblasts) that have been actively and long involved in centripetal migration processes, as well as the Kurgan oblast, a predominantly rural region with low life expectancy and significant migration outflow to neighboring urban agglomerations of the Urals.

In the Asian part of Russia, a decrease in the number of people older than retirement age will most likely be observed in the Irkutsk and Kemerovo oblasts, as well as in the Jewish Autonomous oblast. These regions are located in the zone of the earliest development of Siberia and the Far East and therefore, in contrast to the more northern territories, are characterised by an older population. At the same time, each of these constituent entities of the Russian Federation is located in the zone of attraction of a larger and more attractive neighbour for migration (for Irkutsk and Kemerovo oblasts it is Novosibirsk and, to a lesser extent, Krasnoyarsk, for the Jewish Autonomous oblast - Khabarovsk), which also explains the decrease in the absolute number of pensioners.

The most primitive analysis using the growth rate of the share of pensioners at the regional level over three- and five-year periods revealed the effect of demographic waves in 66 regions: the ageing rate of the population will slow down in 2025-2030 and then accelerate in 2030-35. The exceptions are a few groups of regions, listed below.

1. Regions where the rate of ageing in all three periods is increasing (Moscow oblast, St. Petersburg, Sevastopol, Magadan oblast, Tula oblast). The first three regions are characterised by high migration growth of the working-age population, which will rapidly age in the next 15 years. The Magadan oblast, as a region of new development, is "getting old" late: the main migration growth occurred in the 1970s and 80s, and its members will enter retirement age in the medium term. Tula region is an example of a region characterised by an extremely high level of demographic old age: its proximity to the Moscow urban agglomeration becomes the main reason for the increase in ageing in 202035, acting as a driver of the migration outflow of the working-age population.

2. The Yamalo-Nenets Autonomous Okrug, where not only a slowdown in ageing will be observed, but also a "rejuvenation" of the population until 2030. The reason for this is the high migration growth of the working-age population, which is projected in connection with the implementation of large-scale infrastructure projects in the region's territory.

3. Regions where the pace of ageing will decline:

a. "ethnic" regions with a low level of demographic old age (Dagestan, Ingushetia, Chechen and Tuva republics);

b. "ethnic" regions with an "older" population, where a decrease in migration loss is expected (Republic of Kabardino-Balkaria, Karachay-Cherkessia, North Ossetia, Kalmykia); 
c. demographically old regions in which the resources for migration outflow will be exhausted (Mordovia, Chuvashia, Tambov and Ulyanovsk oblasts). In the Chuvash Republic, a relatively high birth rate is added to this factor.

In light of the planned increase in the retirement age for 2019-2028, of particular interest is the question of how this measure will change the levels of the pension burden in the regions. Let's start with the dynamics of the indicator with a constant retirement age (Figure 8). In this case, the smallest increase in the pension burden rate would be the demographically old regions of Central Russia, where, despite the existing potential to increase life expectancy, the effect of a high base would lead to a limited increase of 5-15\%. Another group of regions characterised by small changes in the coefficient are the regions of Siberia and the Far East, due first of all to both a lower life expectancy than average Russian values and a migration outflow of older people. In the Sverdlovsk, Chelyabinsk and Novosibirsk regions, such trends would also be supplemented by a migratory influx of working-age persons (agglomeration centers of these subjects of the Russian Federation are attractors of migrants at the macro-regional level).

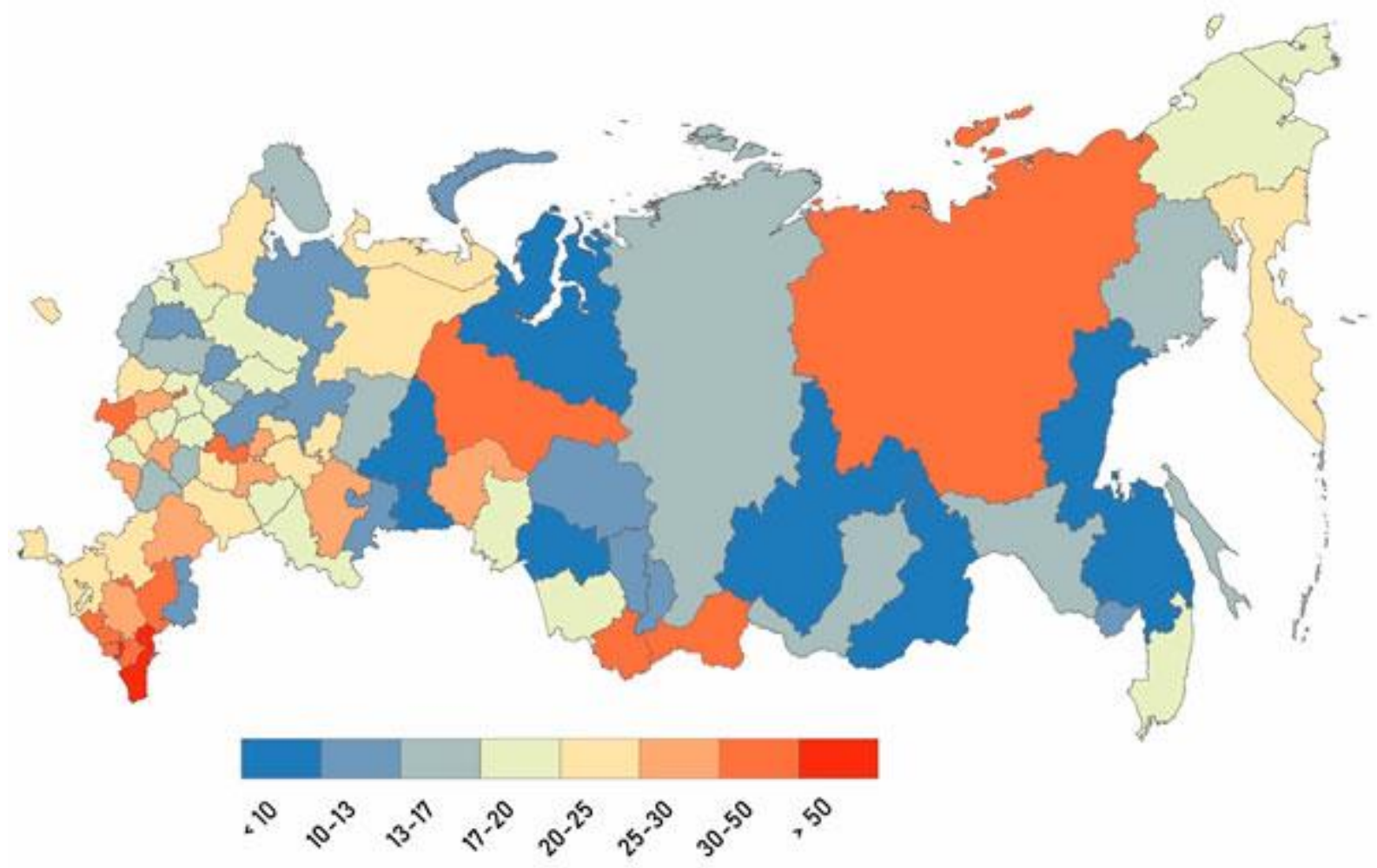

Figure 8. The growth of the pension burden rate in the regions of Russia, 2018-2035, \%

Source: Compiled by the authors based on (Rosstat 2017a).

Note: The boundaries of working age, 15-54 (59) years, remain unchanged.

Average growth rates in the medium term would be observed in areas of the south of Russia (Krasnodar Krai, Rostov Oblast), which already have a rather high level of demographic old age, supplemented by an influx of migrants in older age cohorts (Mkrtchyan 2014). The same characteristics are also observed in the Volga region, where there is a "reserve" of demographic ageing in the form of more numerous age cohorts of pre-retirement age than in Central Russia or the North-West in rural areas. 
The greatest increase in the demographic burden would be in regions with a low level of population ageing (the North Caucasus, especially its eastern sector, Tuva, Altai, Yakutia). The main driver of such trends will be a decrease in the high fertility in these regions by the end of the period under review due to the continuation of active urbanization (Karachurina 2007).

High rates are also observed in the "old" regions: Moscow, the Bryansk oblast and Mordovia. The last two regions can be considered part of the long belt of gravitation toward the Moscow agglomeration, so that, in comparison with the traditional donor regions of Central Russia, it seems to the authors that the potential for migration outflow from these entities will still not be exhausted in the next 10-15 years. Moscow may "age" more rapidly due to both the tendency to a decrease in the already minimal birth rates and the ageing of numerous generations of migrants from previous years (while the migratory influx of the working-age population, on the contrary, will decrease).

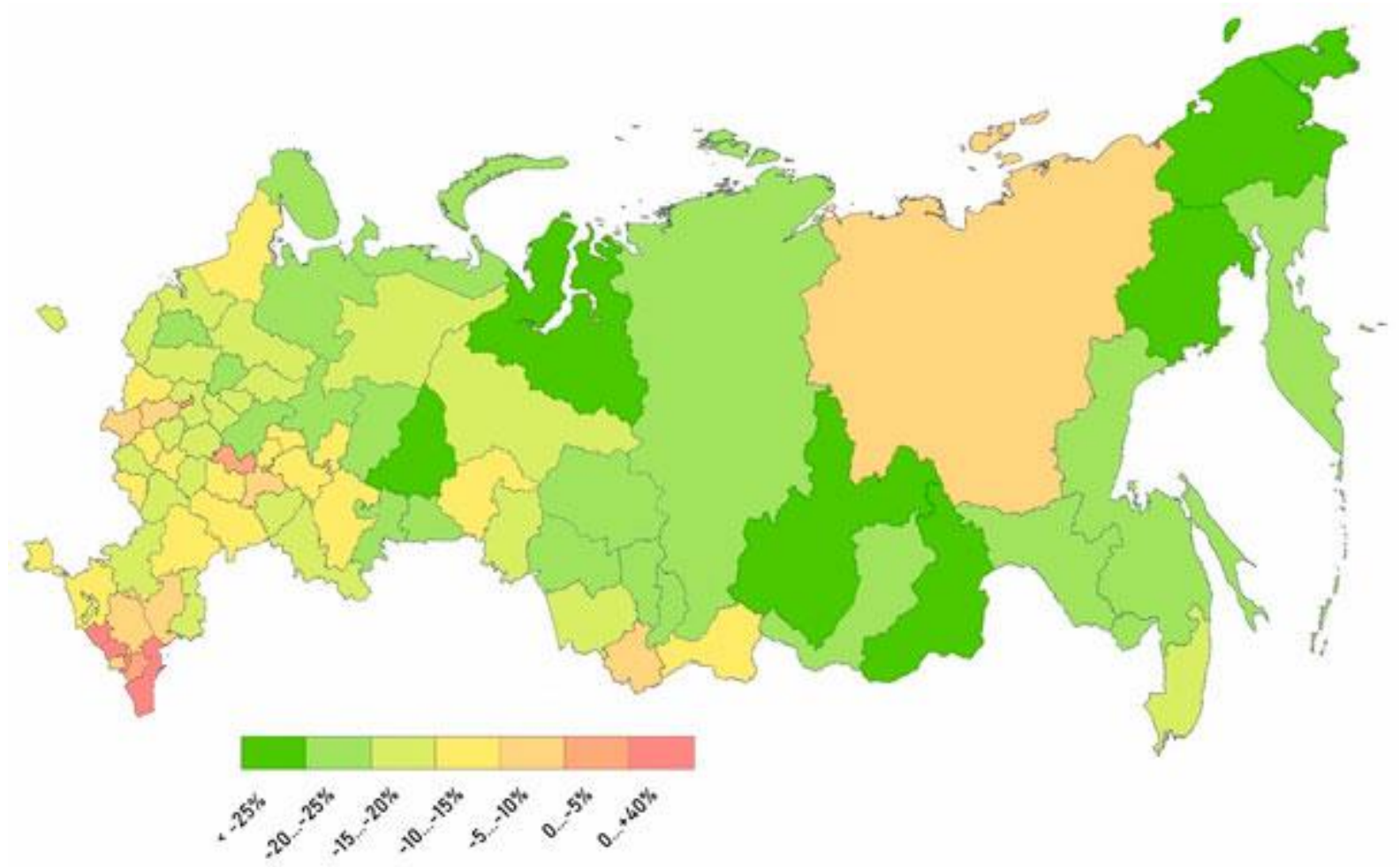

Figure 9. Growth in the pension burden rate, taking into account the increase in the retirement age, 2018-2035, \%

Source: Compiled by the authors based on (Rosstat 2017a).

Note: For 2018, the boundaries of the working age are 15-54 (59) years, for 2035 - 15-59 (64) years according to the accepted option of raising the retirement age.

The application of the current option to increase the retirement age (Figure 9) will reduce the pension burden rate in most regions of Russia. Regional differences are due to the age structure of the population (the greatest "gain" would be observed in the northern and eastern regions of "Soviet" development, where the population is younger (more people would enter retirement age in 2018-2035)). Features of migration also play a role (these same territories are characterised by 
a high migration loss of older people): having earned capital in the "north", the population seeks to spend its old age in the southern regions or large cities of the European part of Russia.

As for the end result, in order to stabilize the ratio of official pensioners and persons of working age, in 17 years an increase in the retirement age may again be necessary - even taking into account the current increase in the retirement age, ongoing ageing of the population will lead to the return by the start of 2036 to a pensioner demographic burden rate at the 2023-2025 level. Moreover, in the North Caucasus republics, which have significant differences in the age structure of the population from other regions of the country (simple reproduction mode), the burden will exceed even current values.

\section{THE PROPORTION OF THE RETIREMENT-AGE POPULATION IN THE REGIONS OF RUSSIA: DIFFERENTIATION AT THE MUNICIPAL LEVEL}

Analysis of demographic ageing at the regional and macroregional levels can be overly generalized. This fact becomes noticeable at a multiscale examination: the variation in the proportion of people over retirement age for 12 macro-regions is 1.84 times lower than for 2,312 municipalities. It is worth noting a more significant increase in the coefficient during the transition from the macro-regional to the regional level than from the regional to the municipal level (1.62 times versus 1.14, respectively). This can be explained by the fact that municipalities, in contrast to regions, whose framework was formed based on historical factors, were formed later and "normatively" (made homogeneous in terms of population and economic potential of the territory). At the same time, some macro-regions "smooth out" differences, including regions with a significantly different age structure of the population (for example, the Angara-Yenisei region, which includes the Krasnoyarsk Krai and the Republic of Tuva).

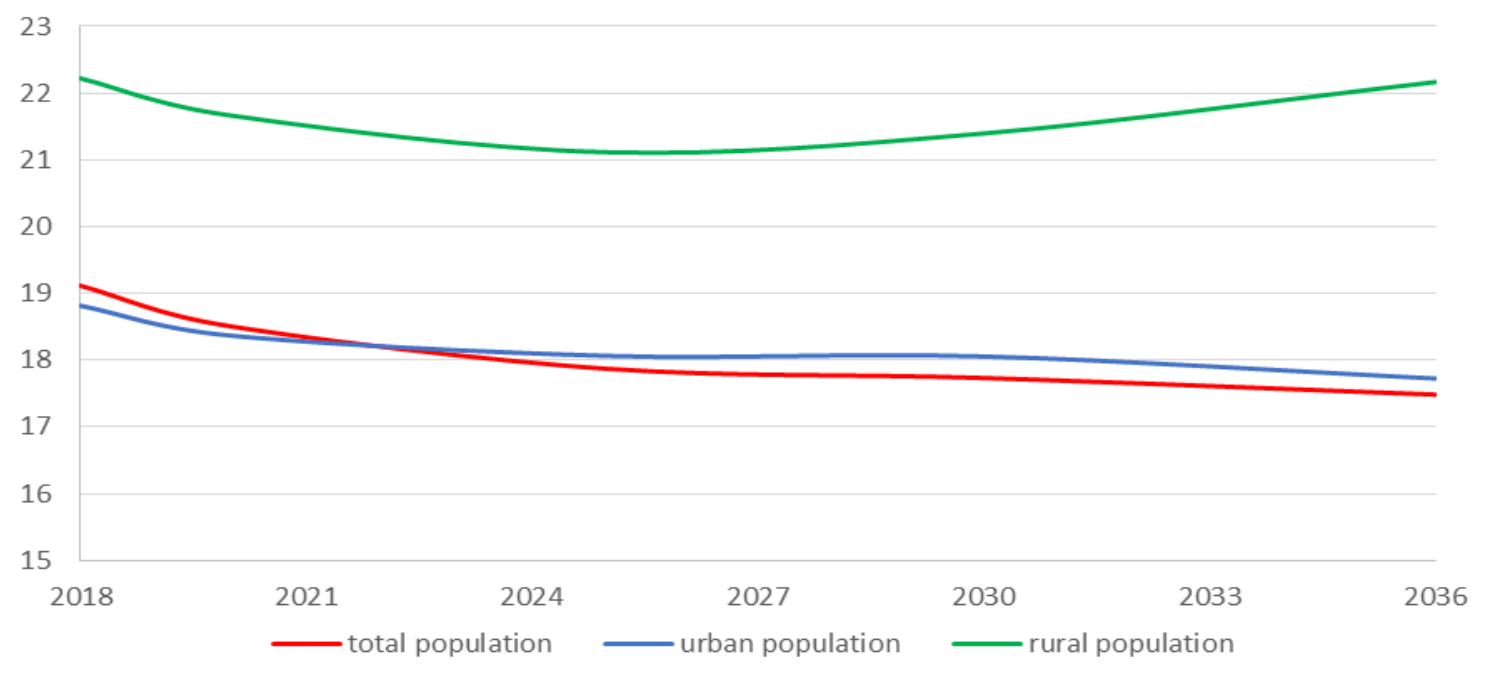

Figure 10. Coefficient of variation in the proportion of persons of retirement age (men 60+, women 55+) for the regions of the Russian Federation, 2018-2035, \%

Source: Compiled by the authors based on (Rosstat 2017a).

Note: Retirement age limits are given until 2019. 
Large units do not allow one to reveal either the true nature of the differences between extreme values at the local level, or intra-regional differentiation (Openshaw 1983), which in recent years has become increasingly noticeable in comparison with inter-regional differentiation (Shevchuk 2018).

Let's start by looking at the variations in the level of demographic old age (according to the "pension" boundaries) over time. By 2036, the variation in the proportion of pensioners in the regions of Russia will decrease (by 1.6 percentage points; Figure 10), which will largely be due to the regions "catching up" with the majority of subjects of the Russian Federation with the minimum percentage of pensioners (Chechnya, Tuva, Yakutia, Ingushetia, Khanty-Mansi Autonomous Okrug, Yamalo-Nenets Autonomous Okrug, Nenets Autonomous Okrug and Chukotka Autonomous Okrug). Russian cities in different regions are more similar than rural areas, more dependent on physical and geographical conditions (it's enough to compare the small "dying" villages of the forest zone and the large southern villages). The rural population of the regions has higher values of the coefficient of variation (rural areas have "hypertrophied" characteristics of the age structure of the regions - in Central Russia, rural peripheral areas are the "oldest" and, for example, in the North Caucasus the proportion of pensioners in rural areas is minimal).

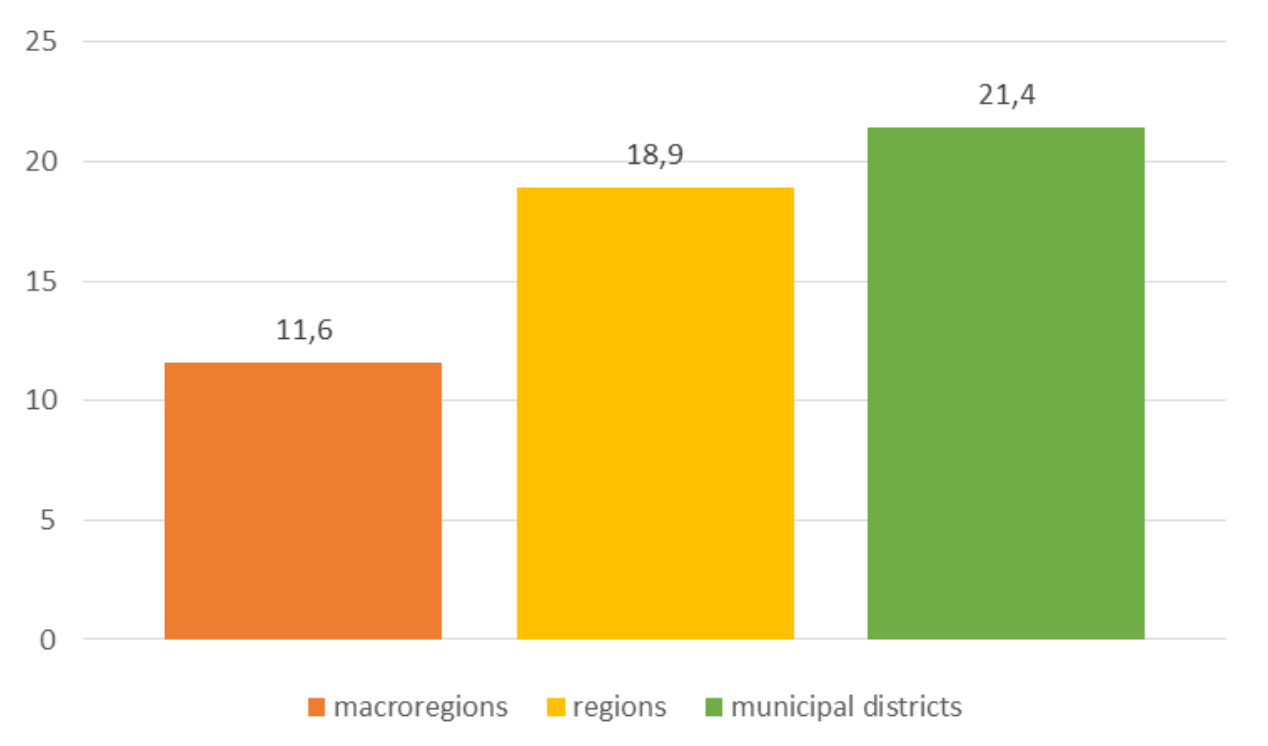

\section{Figure 11. The multi-scale coefficient of variation of the proportion of people older than retirement age (men 60+, women 55+), 2016, \%}

Source: Compiled by the authors on the basis of the Database of municipalities (Rosstat 2018a).

Based on the data of municipal statistics at the level of 2,312 primary units (urban districts, municipal districts and cities of federal significance), a cartogram of the share of persons in retirement age (men over 60 and women over 55 years) in the total population of the corresponding municipality was constructed as of January 1, 2016 (Figure 11). A similar date was selected taking into account the low availability of the most relevant $(2017,2018)$ data at the municipal level in some regions.

The main problems in the analysis (especially when it comes to comparison in dynamics) are changes in the administrative-territorial and municipal divisions that occur annually. Another 
important drawback of the municipal statistics system is the aggregation of data only by region, which makes even automated uploading extremely difficult. Many domestic regional researchers, for example N. Zubarevich (Zubarevich 2012), point to the low quality of statistics in some Russian regions.

Table 2. Municipal statistics in Ingushetia, 2016

\begin{tabular}{l|c|c|c}
\hline $\begin{array}{l}\text { Administrative- } \\
\text { Territorial Units of } \\
\text { Ingushetia }\end{array}$ & $\begin{array}{c}\text { Total population, } \\
\text { persons }\end{array}$ & $\begin{array}{c}\text { Population over retirement age } \\
\text { (men 60+, women 55+), } \\
\text { persons. }\end{array}$ & $\begin{array}{c}\text { Calculated share of } \\
\text { persons of retirement age } \\
\text { (men 60+, women 55+) } \\
\%\end{array}$ \\
\hline UO* Karabulak & 39,614 & 5253 & 13.26 \\
UO Malgobek & 36,870 & 4731 & 12.83 \\
UO Magas & 7,818 & 966 & 12.36 \\
UO Nazran & 116,020 & 13,793 & 11.89 \\
Dzheyrakhsky district & 2,917 & 341 & 11.69 \\
Nazranovsky district & 9,8102 & 11,463 & 11.68 \\
Sunzhensky district & 123,212 & 14,395 & 11.68 \\
Malgobeksky district & 5,5408 & 6473 & 11.68 \\
\hline
\end{tabular}

*UO - Urban Okrug

Source: Compiled by the authors on the basis of the Database of municipalities (Rosstat 2018a).

An example is the Republic of Ingushetia, where in 4 out of 8 municipalities the estimated proportion of people older than retirement age coincided to $0.01 \%$ (table 2). The likelihood that such an event is a reflection of the real situation, and not a statistical error or falsification, is extremely small, especially considering the large population and significant differences in the population density of these municipalities. Interestingly, in the neighboring regions of the North Caucasus, such phenomena are not observed.

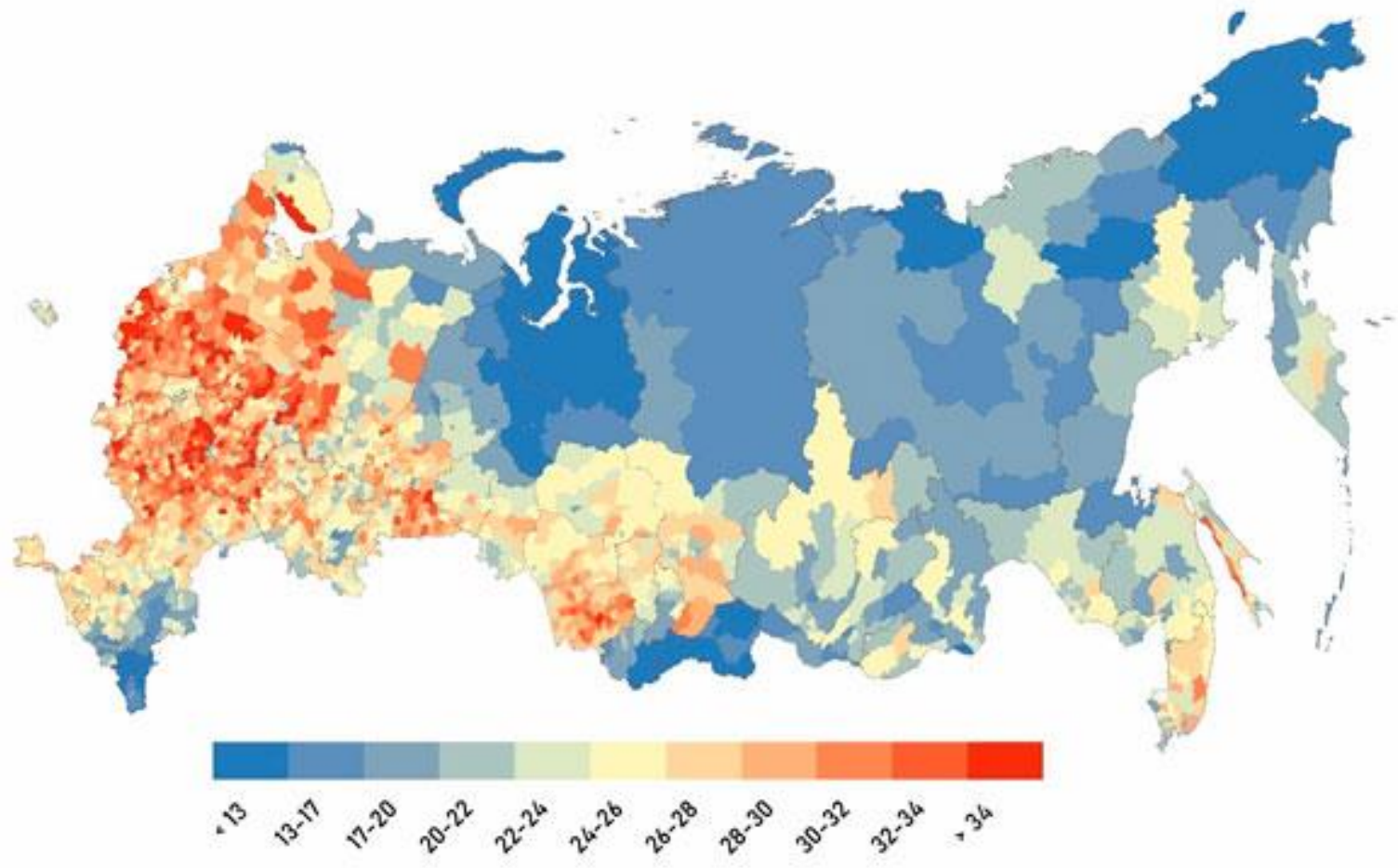

Figure 12. The proportion of people over retirement age (men $60+$, women $55+$ ) by firstlevel municipalities, 2016, \% 
Source: Compiled by the authors on the basis of the Database of municipalities (Rosstat 2018a).

Cartographic visualization at the municipal level (Figure 12) allows one to clearly distinguish the areas with the highest proportion of an "old" population (Central Russia, NorthWest), with a relatively high share (Southern regions with predominant Russian ethnicity, Volga Region, Urals, the main settlement zone in Siberia and the Far East) and with a low share (areas of new development of the Far North, ethnic territories of the North Caucasus, Siberia and the Far East).

The main reason for such differences is the demographic history of these territories: areas with a maximum proportion of the elderly are territories that have served as migration donors since the turn of the 20th century. "Middling" territories are those that were actively settled throughout the 20th century and have begun to show negative trends in migratory and natural movement only in the last 30 years. The lowest proportion of elderly people is observed in territories with high natural growth and an influx of predominantly young people (oil-producing autonomous okrugs).
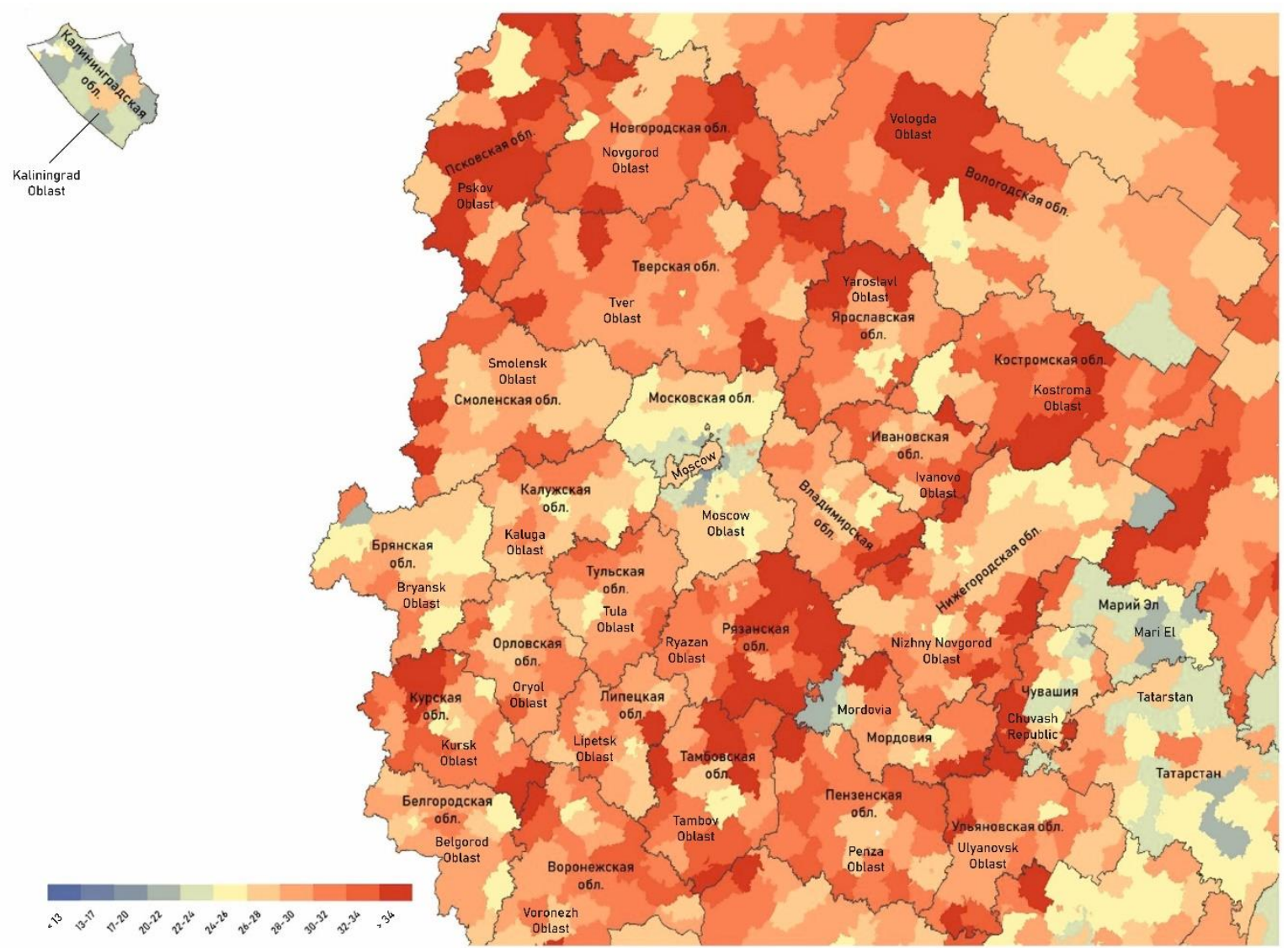

Figure 13. The proportion of people older than retirement age (men $60+$, women $55+$ ) by first-level municipalities, Central Russia, 2016, \%

Source: Compiled by the authors on the basis of the Database of municipalities (Rosstat 2018a).

Central Russia is one of the demographically oldest regions of Russia. On the cartogram (Figure 13), you can notice several main features. 
1. A "youth peak" in the Moscow metropolitan area, where lower real estate prices in municipalities of the Moscow Region, directly adjacent to the Moscow Ring Road, attract migrant workers from all over the country. Examples of such municipal districts and urban districts are Mytishchi, Leninsky, Shchelkovsky and Krasnogorsk districts, urban districts of Odintsovo, Ivanteyevka, Reutov, Balashikha, Domodedovo, Lobnya, Bronnitsy, Dzerzhinsky, Kotelniki (the proportion of people over retirement age is 15-23\%).

2. "Young" regional centers. The capitals of the constituent entities of the Russian Federation are the focus of intra-regional migration of a younger population. Most often, lower values for the proportion of elderly are observed in municipalities surrounding regional centers (urban districts). A similar phenomenon is associated with the formation of small-scale clusters of satellite settlements of the regional center, where active housing construction is sometimes carried out. Examples of such municipalities are the Vologda urban district and the Vologodsky district, Smolensk and Smolensky district, Penza and Penzensky district.

3. Azonal "islands of youth" where penitentiary facilities are located. The most illustrative example is the west of the Republic of Mordovia - the Zubovopolyansky district (20.7\%), where about 15 institutions of the Federal Penitentiary Service are located (the legacy of the famous Dubravny Gulag Labour Camp). According to rural researchers, about $21 \%$ of the population in this region are people serving prison sentences (Averkieva 2015). The low rate of demographic old age in the Tonshayevsky district in the extreme north-east of the Nizhny Novgorod oblast (20.5\%), on the territory of which there are also 3 correctional colonies, has a similar nature.

Also in this category are the municipalities of the Kaliningrad oblast, which is a semiexclave surrounded by the territories of Poland and Lithuania. The relative "youth" of the region's population is associated with a positive migration growth of the young population practically throughout the entire post-war period from the beginning of the settlement of East Prussia by Soviet citizens, as well as with the deployment of military units on the territory of the outpost region.

4. The "young" south-west of the Bryansk oblast. A relatively low proportion of pensioners is observed in the zone most affected by the consequences of the Chernobyl accident (Gordeyevsky, Novozybkovsky, Zlynkovsky districts). Such values are associated with a relatively high fertility and characteristics of migration processes (Rybakovsky 1992: 4548): after the accident, the majority of those most vulnerable to radiation exposure (children, the elderly) left the settlements, but over time, many (mostly young ) residents returned to their place of residence (a zone with the right to resettle). Also, against the background of a significant decrease in fertility in the first 10-15 years after contamination of the territory with radionuclides in the late 2000s and early 2010s, there was a compensatory growth, expressed in a positive natural increase in certain years.

5. The demographically "old" periphery of the regions. This type includes the underdeveloped marginal territories, where the migration outflow began earlier. These are above all regions of the western sector which at first served as a resource for the spasmodic growth of the Moscow and St. Petersburg urban agglomerations in the late 19th - first half of the 20th century, and then were devastated by the Great Patriotic War (Smolensk, Pskov, Novgorod, Tver oblasts). 
The highest share of elderly people is observed in municipalities far from transport routes that do not have any significant centers of economic activity on their territory: the Smolensk borderland (Shumyachsky, Monastyrshchinsky districts), the periphery of the Yaroslavl, Tver and Novgorod oblasts, caught between the St. Petersburg - Urals and Moscow- St. Petersburg highways (Vesyegonsky, Breytovsky districts). Separately, it is worth mentioning the periphery of the Vladimir, Ivanovo, Nizhny Novgorod, Ryazan and Tambov oblasts, where the "oldest" areas are located in areas of relatively lower density and shallow settlement, which is directly related to the higher forest cover of these territories (lower and wetter areas with less fertile soils - for example, the Meshchera lowland).

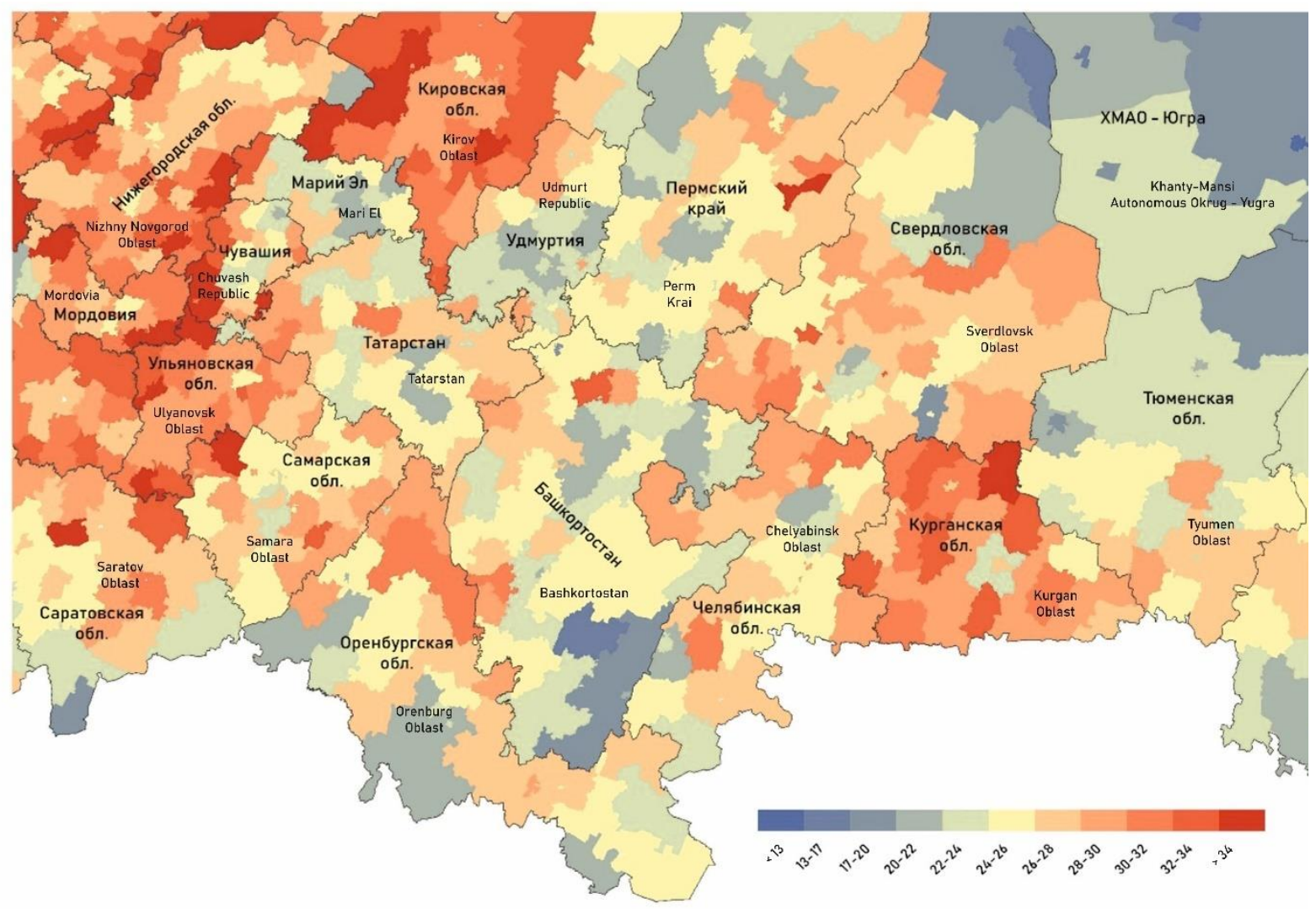

Figure 14. The proportion of people older than retirement age (men 60+, women 55+) by first-level municipalities, Volga and Ural, 2016,\%

Source: Compiled by the authors on the basis of the Database of municipalities (Rosstat 2018a).

The Volga-Ural region (Figure 14) is one of the most multi-ethnic in the Russian Federation. The different rate of the demographic transition among representatives of different ethnic groups is the main reason for the mosaic pattern of demographic ageing in the macroregion. Another significant factor is the greater importance of rural areas in comparison with Central Russia both in the settlement system and in economic activity in the territory of these constituent entities of the Russian Federation.

Among the main spatial patterns of the age structure of the population, the following can be distinguished. 
1. A less old population in "ethnic" municipalities. Within the republics, the differentiation between the older, predominantly Russian regions (West Mari El, Southwest Chuvashia, areas along the Kama and Volga rivers in Tatarstan) and the younger, populated representatives of titular ethnic groups is pronounced.

2. However, such a relationship is not universal. Thus, the municipalities of Mordovia are characterised by approximately the same level of old age. The main reasons for the lack of differentiation are the high degree of overlap in the resettlement of representatives of the Erzyan, Mokshan, Tatar and Russian ethnic groups in the region, as well as the high degree of assimilation of the titular peoples.

3. A "young" borderland. A relatively low proportion of pensioners is also observed in the municipalities of the Orenburg (Sol-Iletsky, Dombarovsky districts) and Saratov (Aleksandrovo-Gaysky, Novouzensky districts) regions along the border with Kazakhstan, where the ethnic composition underwent significant changes in the post-Soviet period due to a much higher birth rate of Kazakhs.

4. The demographically oldest regions are represented by the territories of the early Russian colonization of the Urals and the south of Western Siberia (the south of the Sverdlovsk and Tyumen, Chelyabinsk and Kurgan oblasts).

The North Caucasus is characterised by minimal demographic old age at the level of individual regions (Chechnya, Ingushetia, Dagestan). When considered at the municipal level (Figure 15), the macroregion is characterised by much less mosaicity in contrast to the Volga and Cis-Urals, which is associated with a higher compactness of local ethnic groups. Among the geographical features of the level of demographic old age, the following can be distinguished.

1. Less elderly "ethnic" municipalities outside the republics of the North Caucasus Federal District. An example is the areas of compact residence of the titular population in the Republic of Adygea (Kuban lowland - Teuchezhsky, Koshekhablsky and Shovgenovsky districts). Yet another example is the regions of the east of the Astrakhan borderland (Volodarsky, Krasnoyarsky) predominantly populated by Kazakhs, as well as the eastern regions of Stavropol Krai, to which there has been an intensive migration flow from Dagestan and Chechnya in recent years (Kursky, Levokumsky, Neftekumsky districts). Municipalities of the Republic of Crimea, where Crimean Tatars compactly live (Belogorsky, Simferopolsky, Sovetsky districts), are also characterised by a younger age structure. A relatively younger population is also observed in areas of low population density in the Volgograd region (Olkhov district, where there is a significant Romani community).

2. The "younger" Krasnodar, Rostov and Stavropol urban agglomerations, which have experienced significant migration growth of the working-age population. Unlike urban agglomerations in other parts of the country, these cities also attract older migrants; for this reason, the proportion of people over retirement age is higher than in the Moscow and Yekaterinburg urban agglomerations. 


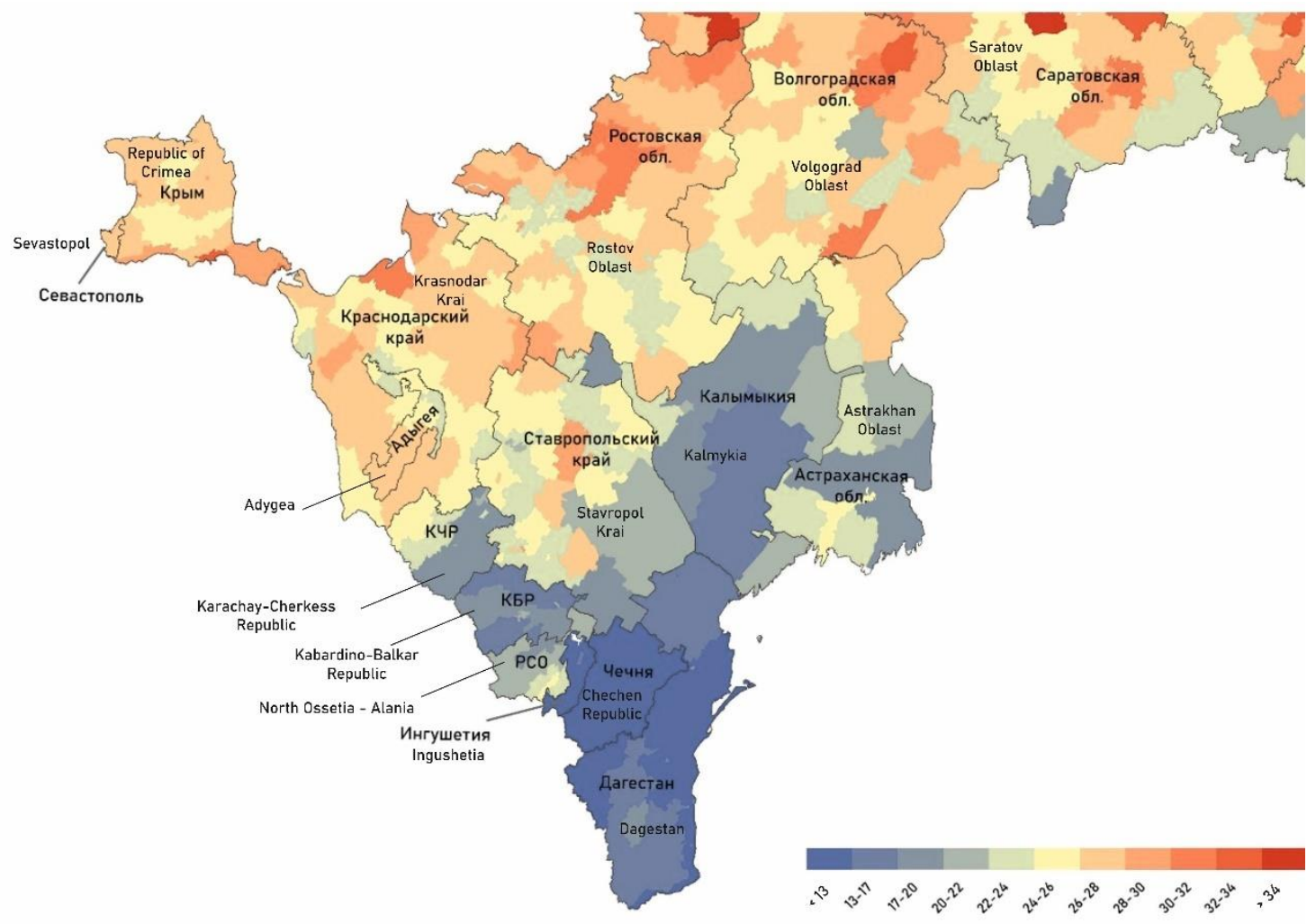

Figure 15. The proportion of people over retirement age (men $60+$, women $55+$ ) by firstlevel municipalities, South, North Caucasus and Crimea, 2016, \%

Source: Compiled by the authors on the basis of the Database of municipalities (Rosstat 2018a).

3. The peripheral regions of the "Russian" regions that have experienced significant migration outflows. Above all, it is the Rostov part of the Donets coal basin (Donbass) (Oktyabrsky, Krasnosulinsky and Kamensky districts, urban okrugs Kamensk-Shakhtinsky, Zverevo, Donetsk, Gukovo, Shakhty, Novoshakhtinsk) which stands out. Also standing out in the Krasnodar Krai are the northwestern and northeastern territories, which, like the Russian Donbass during the transformation crisis, lost their monospecialization (fish farming in the Primorsko-Akhtarsky district of the Kuban, areas of risky farming in the dry steppe Novopokrovsky, Beloglinsky district of the Krasnodar Krai, Peschanokopsky district of the Rostov Oblast). 


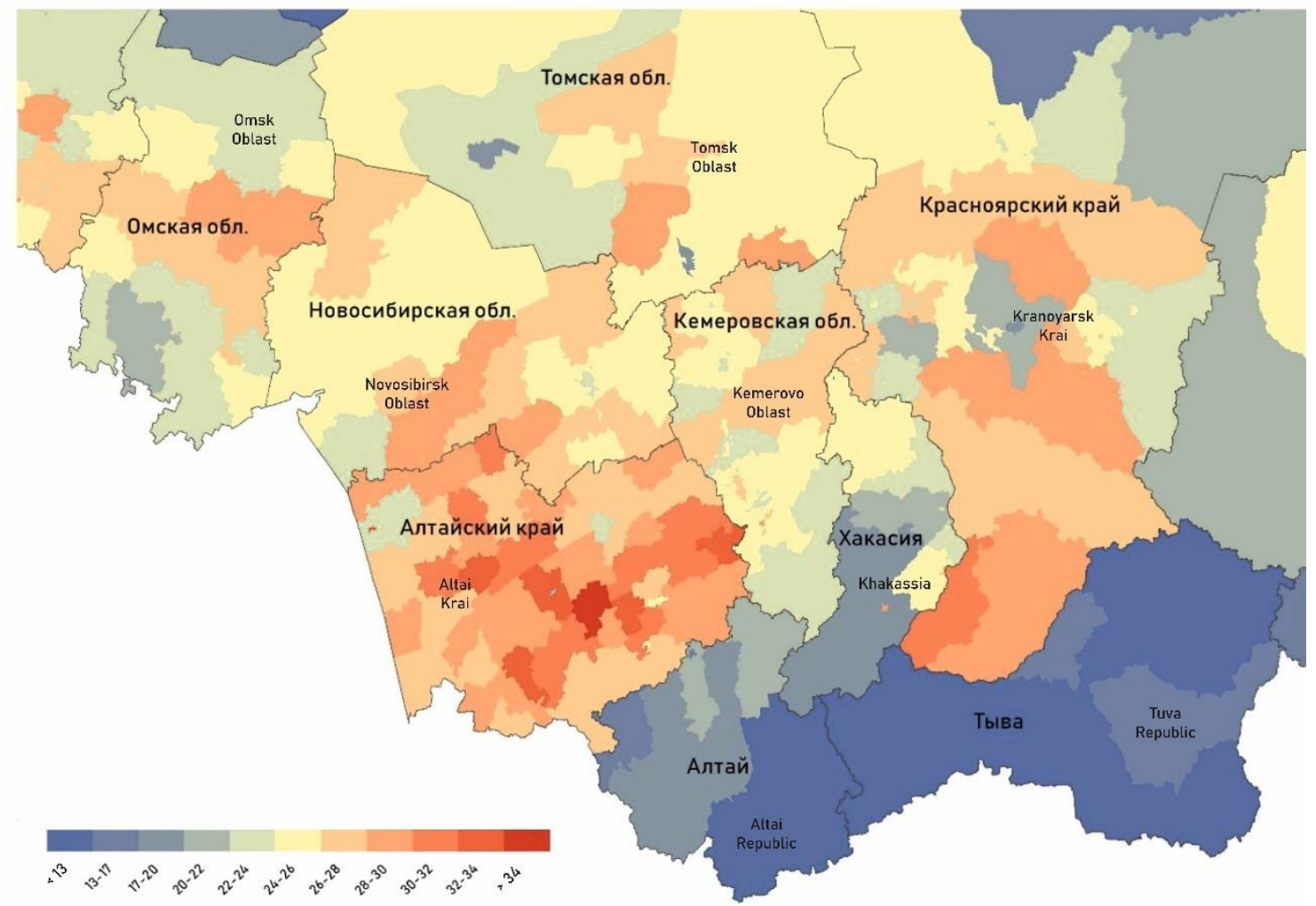

Figure 16. The proportion of people over retirement age (men 60+, women 55+) by firstlevel municipalities, South Siberia, 2016, \%

Source: Compiled by the authors on the basis of the Database of municipalities (Rosstat 2018a).

South Siberia is another polarised macroeconomic region in terms of demographic ageing (Figure 16). The age composition of the population of municipalities is characterised by the following features:

1. a student center on a federal scale - the urban okrug of Tomsk, where the proportion of pensioners is lower than in other regional centers;

2. relatively "older" territories of early agricultural development with a high density of rural population (Altai Krai, the south of the Novosibirsk Oblast, the Minusinsk Hollow in the Krasnoyarsk Krai and the Republic of Khakassia).

\section{CONCLUSION}

An analysis of the possible relationship between the pace and level of ageing of the population, on the one hand, and an increase in the retirement age, on the other hand, indicates the absence of such a connection. The reason for this is the use of other measures to increase the reliability of the pension system (for example, stimulating investments in non-state funds) and the individuality of demographic scenarios in different countries. The raising of the retirement age could be determined more by the current socio-economic situation of countries than by the demographic context, and be a measure designed to solve the financial problems of the state, not to increase the 
reliability of the pension system (Roik 2011).

A universal dependence that would indicate a definite slowdown in the ageing of the population when a high proportion of the elderly is reached has not been identified, which is associated with a variety of demographic transition scenarios and the peculiarities of the migration regime in different countries and regions. Nevertheless, in the Russian Federation, which so far continues to age mainly due to a decrease in fertility, a high level of ageing is associated with the late completion of the demographic transition at the regional level. The existence of such a pattern is connected mostly with the ethnic-political principle of administrative territorial division inherited by Russia from the Soviet Union, which preserves at the statistical level ethnic and urbanrural differences. Thus, the basis for regional differentiation in the future will be the long-term preservation of traditionalist demographic attitudes in the "ethnic" constituent entities of the Russian Federation.

An analysis of the prospects of the pension burden for the period until 2036 shows only a temporary effect of raising the retirement age to solve the problem of imbalance in the joint pension system: an increase in the burden of pensioners after 2028 will be observed in almost the majority of regions. Given the fact that in Russia there is a federal pension system that is independent of the imbalance at the level of individual entities, raising the retirement age will temporarily solve the problem of a pension fund deficit. In the future, however, the government will again face a choice: to raise the retirement age against the background of a continuing increase in the survival age at older ages or to apply more advanced measures.

According to the current version of the demographic forecast, the regional heterogeneity of the processes of demographic ageing in Russia will decrease. With the completion of the demographic transition, differences in the migration situation will come to the fore, the driver of which becomes the local level of socio-economic development of territories. This fact is confirmed by considering the territorial ranges of extreme values of the share of persons of retirement age in Russian municipalities. When moving to a more granular level, the coefficient of variation increases (from $18.9 \%$ for 85 regions to $21.4 \%$ for 2,312 municipalities and cities of federal significance): intra-regional rather than inter-regional differences come to the fore, which reflects the ongoing concentration of the population in the centers of economic growth (regional centers, federal cities and clusters of settlements surrounding them - urban agglomerations).

\section{REFERENCES}

Averkiyeva K.V. (2015). Geografiya i ekonomika rossiyskoy penitentsiarnoy sistemy. Demoscope Weekly, 651-652. (In Russ.) Retrieved from http://demoscope.ru/weekly/2015/0651/tema01.php

Belyayeva L.A. (2006). Sotsial'naya stratifikatsiya i bednost' v regionakh Rossii. Sociological Studies, 9, 52-62. (In Russ.)

Disney R., Johnson P. (Eds.) (2001). Pension systems and retirement incomes across OECD countries. Cheltenham: Edward Elgar Publishing. 
Dorn D., Sousa-Poza A. (2010). «Voluntary» and «involuntary» early retirement: an international analysis. Applied Economics, 42(4), 427-438. doi: 10.1080/00036840701663277

Karachurina L.B. (2007). Regional'nye osobennosti rossijskoj demograficheskoj situacii. Demoscope Weekly. 273-274. (In Russ.) Retrieved from http://www.demoscope.ru/weekly/2007/0273/analit05.php

Lutz W., Sanderson W., Scherbov S. (2008). The coming acceleration of global population ageing. Nature, 451(7179), 716. doi:10.1038/nature06516.

Maleva T.M., Sinyavskaya O.V. (2010). Pension age increase: pro et contra. Journal of the New Economic Association, 8, 117. (In Russ.)

Mironova A.A. (2014). Rodstvennaya mezhpokolennaya solidarnost' v Rossii. Sociological Studies, 10, 136-142. (In Russ.)

Mkrtchyan N.V. (2014). O vliyanii migratsii na vozrastnoy sostav naseleniya regionov, gorodov i rayonov Rossii. The Institute of Economic Forecasting of the Russian Academy of Sciences, 12, 381-396. (In Russ.) Retrieved from https://ecfor.ru/publication/o-vliyanii-migratsii-navozrastnoj-sostav-naseleniya/

Openshaw S. (1983). The modifiable areal unit problem. Norwick: Geo Books.

Pensionnyy fond Rossiyskoy Federatsii [Pension fund of Russia Federation] (2018). Otkrytyye dannyye 2018 [Open data]. (In Russ.). Retrieved from http://www.pfrf.ru/opendata 7706016118-pensioners (data downloaded on 15.12.2018).

Reher D.S. (2011). Economic and social implications of the demographic transition. Population and development review, 37, 11-33. doi: 10.2307/41762397

Roik V.D. (2011). Pensionnaya reforma v Rossii: trudnyy put' stanovleniya strakhovykh institutov. ECO, 3, 4-23. (In Russ.)

Rosstat (2017a). Predpolozhitel 'naya chislennost' naseleniya Rossii do 2035 goda 2017 [Estimated population of Russia until 2035]. (In Russ.). Retrieved from http://www.gks.ru/wps/wcm/connect/rosstat_main/rosstat/ru/statistics/population/demograph y/\# (data downloaded on 09.02.2019).

Rosstat (2017b). Rabochaya sila, zanyatost'i bezrabotitsa v Rossii 2017. (In Russ.) Retrieved from http://www.gks.ru/bgd/regl/b18_61/IssWWW.exe/Stg/pril/r_3.xls (data downloaded on 09.02.2019).

Rosstat (2018a). Baza dannykh pokazateley munitsipal'nykh obrazovaniy 2018 [Database of municipal indicators]. (In Russ.). Retrieved from http://www.gks.ru/dbscripts/munst/ (data downloaded on 09.02.2019).

Rosstat (2018b). Regiony Rossii 2018 [Regions of Russia]. (In Russ.). Retrieved from http://www.gks.ru/bgd/regl/b18_14p/IssWWW.exe/Stg/d01/02-05.doc (data downloaded on 18.02.2019).

Rybakovskiy L.L. (1992). Demograficheskiye posledstviya avarii na Chernobyl'skoy AES. Sociological Studies, 9, 40-50. (In Russ.)

Shcherbakova Ye.M. (2014). Stareniye naseleniya: mirovyye tendentsii. Demoscope Weekly, 601-602. (In Russ.). Retrieved from http://demoscope.ru/weekly/2014/0601/barometer601.pdf 
Shevchuk E.I. (2018, april). Adjusting research scale for spatial socio-economic disparities. Report presented during Scientific Youth Forum 'Lomonosov-2018'. Moscow, Russia. (In Russ.)

Sonina Yu.V., Kolosnitsyna M.G. (2015). Pensioners on the Russian labour market: trends of economic activity in pension age. Demographic Review, 2(2), 37-53. (In Russ.). doi: 10.17323/demreview.v2i2.1781.

UN World Population Division (2017). World Population Prospects 2017. Retrieved from https://population.un.org/wpp/DataQuery (data downloaded on 17.01.2019).

Vishnevsky A.G. (2005). In Praise of Old Age. Otechestvennye zapiski, 3, 24. (In Russ.)

Vishnevsky A.G. (2015). Mortality in Russia: the second epidemiologic revolution that never was. Demographic Review, 1(4), 5-40. (In Russ.). doi: 0.17323/demreview.v2i5.5581.

Worldbank (2017). World Bank Open Data 2017. Retrieved from https://data.worldbank.org/indicator/SP.POP.65UP.TO (data downloaded on 17.01.2019).

Zubarevich N.V. (2012). Sotsial'no-ekonomicheskoye razvitiye respublik Severnogo Kavkaza: kolichestvennyye i ekspertnyye otsenki [Socio-economic development of the North Caucasus republics: quantitative and expert assessment]. Independent Institute for Social Policy. (In Russ.). Retrieved from http://atlas.socpol.ru/portraits/r_sk.shtml (data downloaded on 25.09.2018). 